\title{
The Effect of Reaction Control System Thruster Plume Impingement on Orion Service Module Solar Array Power Production
}

Kristen M. Bury and Thomas W. Kerslake

Glenn Research Center, Cleveland, Ohio 


\section{NASA STI Program . . . in Profile}

Since its founding, NASA has been dedicated to the advancement of aeronautics and space science. The NASA Scientific and Technical Information (STI) program plays a key part in helping NASA maintain this important role.

The NASA STI Program operates under the auspices of the Agency Chief Information Officer. It collects, organizes, provides for archiving, and disseminates NASA's STI. The NASA STI program provides access to the NASA Aeronautics and Space Database and its public interface, the NASA Technical Reports Server, thus providing one of the largest collections of aeronautical and space science STI in the world. Results are published in both non-NASA channels and by NASA in the NASA STI Report Series, which includes the following report types:

- TECHNICAL PUBLICATION. Reports of completed research or a major significant phase of research that present the results of NASA programs and include extensive data or theoretical analysis. Includes compilations of significant scientific and technical data and information deemed to be of continuing reference value. NASA counterpart of peer-reviewed formal professional papers but has less stringent limitations on manuscript length and extent of graphic presentations.

- TECHNICAL MEMORANDUM. Scientific and technical findings that are preliminary or of specialized interest, e.g., quick release reports, working papers, and bibliographies that contain minimal annotation. Does not contain extensive analysis.

- CONTRACTOR REPORT. Scientific and technical findings by NASA-sponsored contractors and grantees.

- CONFERENCE PUBLICATION. Collected papers from scientific and technical conferences, symposia, seminars, or other meetings sponsored or cosponsored by NASA.

- SPECIAL PUBLICATION. Scientific, technical, or historical information from NASA programs, projects, and missions, often concerned with subjects having substantial public interest.

- TECHNICAL TRANSLATION. Englishlanguage translations of foreign scientific and technical material pertinent to NASA's mission.

Specialized services also include creating custom thesauri, building customized databases, organizing and publishing research results.

For more information about the NASA STI program, see the following:

- Access the NASA STI program home page at http://www.sti.nasa.gov

- E-mail your question via the Internet to help@ sti.nasa.gov

- Fax your question to the NASA STI Help Desk at 301-621-0134

- Telephone the NASA STI Help Desk at 301-621-0390

- Write to: NASA Center for AeroSpace Information (CASI) 7115 Standard Drive Hanover, MD 21076-1320 
NASA/TM-2008-215423

AIAA-2008-5753

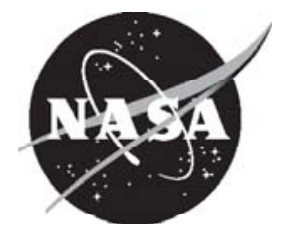

\section{The Effect of Reaction Control System Thruster Plume Impingement on Orion Service Module Solar Array Power Production}

Kristen M. Bury and Thomas W. Kerslake

Glenn Research Center, Cleveland, Ohio

Prepared for the

Sixth International Energy Conversion Engineering Conference (IECEC)

sponsored by the American Institute of Aeronautics and Astronautics

Cleveland, Ohio, July 28-30, 2008

National Aeronautics and

Space Administration

Glenn Research Center

Cleveland, Ohio 44135 


\section{Acknowledgments}

The authors thank Paul Boeder of Boeing for sharing the Boeing erosion model, Julien du Castel of Lockheed Martin for generating PIDYN flux models, Barry Hillard and Boris Vayner of NASA Glenn Research Center for helping to assess Paschen discharge problems, and both Shane Malone and Xiaoyen Wang of NASA Glenn Research Center for providing RCS data and for performing technical reviews of the paper.

This report contains preliminary findings, subject to revision as analysis proceeds.

Trade names and trademarks are used in this report for identification only. Their usage does not constitute an official endorsement, either expressed or implied, by the National Aeronautics and Space Administration.

Level of Review: This material has been technically reviewed by technical management.

Available from

NASA Center for Aerospace Information 7115 Standard Drive

Hanover, MD 21076-1320
National Technical Information Service 5285 Port Royal Road Springfield, VA 22161 


\title{
The Effect of Reaction Control System Thruster Plume Impingement on Orion Service Module Solar Array Power Production
}

\author{
Kristen M. Bury and Thomas W. Kerslake \\ National Aeronautics and Space Administration \\ Glenn Research Center \\ Cleveland, Ohio 44135
}

\begin{abstract}
NASA's new Orion Crew Exploration Vehicle has geometry that orients the reaction control system (RCS) thrusters such that they can impinge upon the surface of Orion's solar array wings (SAW). Plume impingement can cause Paschen discharge, chemical contamination, thermal loading, erosion, and force loading on the SAW surface, especially when the SAWs are in a worst-case orientation (pointed $45^{\circ}$ towards the aft end of the vehicle). Preliminary plume impingement assessment methods were needed to determine whether in-depth, time-consuming calculations were required to assess power loss. Simple methods for assessing power loss as a result of these anomalies were developed to determine whether plume impingement induced power losses were below the assumed contamination loss budget of 2 percent. This paper details the methods that were developed and applies them to Orion's worst-case orientation.
\end{abstract}

\section{Nomenclature}

$\begin{array}{ll}\text { GEO } & \text { geosynchronous earth orbit } \\ \text { GRC } & \text { NASA Glenn Research Center } \\ \text { ITO } & \text { indium tin oxide } \\ \text { LEO } & \text { low Earth orbit } \\ \text { MMH } & \text { monomethyl hydrazine } \\ \text { MMH-HNO } & \text { monomethylhydrazium nitrate } \\ \text { P*D } & \text { pressure multiplied by distance } \\ \text { PIDYN } & \text { Plume Impingement Dynamics } \\ \text { RCS } & \text { reaction control system } \\ \text { SAW } & \text { solar array wings } \\ \text { T } & \text { transmittance } \\ \lambda & \text { wavelength of incident light } \\ \tau & \text { contaminant mass per unit area }\end{array}$

\section{Introduction}

Orion's reaction control system (RCS) consists of $1625-1 b_{\mathrm{f}}$ thrusters. The thrusters are arranged such that their impact on the solar arrays is minimized; however, the solar array wings (SAWs) are in the line of fire of the outer region of the aft RCS thruster plume flow field.

It should be noted that there are 24 RCS thrusters shown in figure 1, but all analyses were performed using updated geometry that stipulates there are four RCS pod clusters each housing four thrusters (two pointed forward and two pointed aft) giving a total of 16 thrusters on the vehicle. 


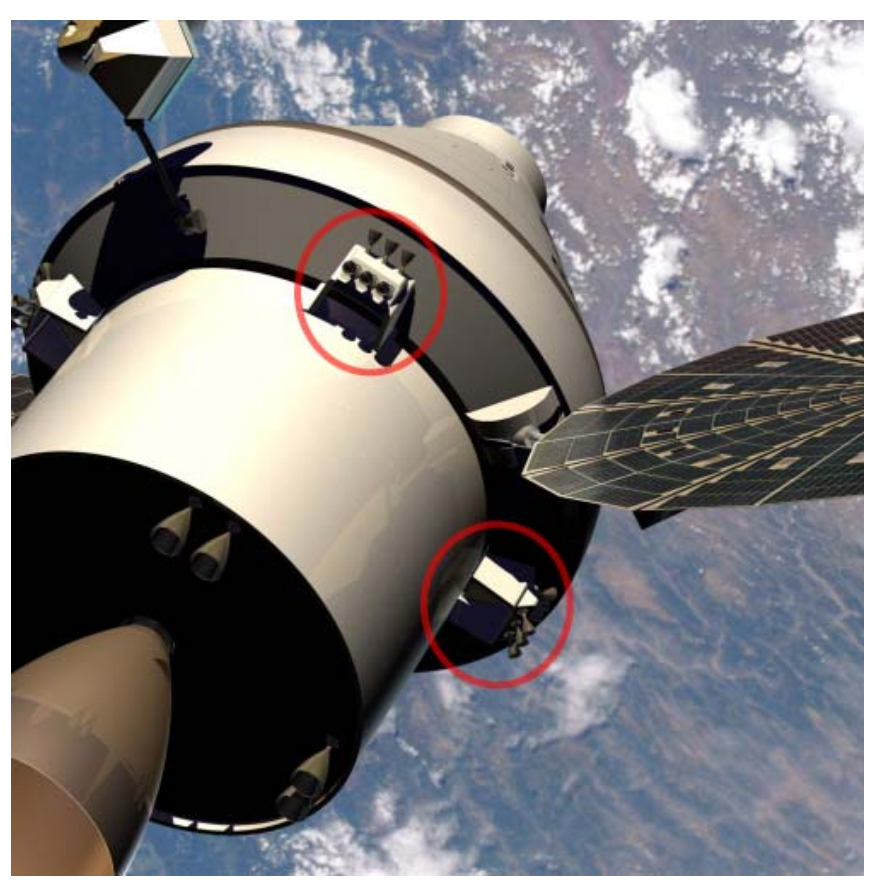

Figure 1.-Diagram of Service Module. RCS pod clusters are circled in red.

Plume impingement can cause Paschen discharges, chemical contamination, thermal loading, erosion, and force loading on the SAWs. These problems can cause degradation of the SAWs' power generation capabilities through electrical shorting, loss in optical transparency, increase in reflectivity of the cells' cover glasses, or overheating of the cells. All assessments in this paper were made assuming the wings were in their worst-case orientation, angled $45^{\circ}$ toward the aft end of the spacecraft. This was considered the worst-case orientation because the solar arrays are physically limited from angling any farther back. Because of this assumption, all assessments should be taken as conservative.

\section{Paschen Discharge}

Paschen discharges are related to the theory of Townsend breakdown in gases. If a free electron is accelerated by an electric field and it acquires enough energy to ionize other neutral atoms that it collides with, these new ions will also gain energy from the electric field to ionize other atoms through collision. This starts a chain-reaction process called an avalanche. The free electrons can be liberated through collisions or photoionization. Photoionization occurs when radiation absorbed by a molecule has higher energy than the molecule's ionization potential. A Paschen discharge occurs when the ions interact with the electrodes on the SAWs. If ions come into close proximity to a charged surface on the solar array, arcing can occur (ref. 1).

When a gas is incident upon a surface like a solar array, the breakdown voltage is based on two parameters: the pressure of the incident gas and the distance between electrodes on the solar array. Paschen curves (see appendix A) are graphs of breakdown voltage as a function of pressure multiplied by distance $\left(\mathrm{P}^{*} \mathrm{D}\right)$ and are available for various pure species. The curves can be used to predict whether a Paschen discharge will occur in a given charging environment. If the $\mathrm{P} * \mathrm{D}$ value is far to the left or right of the minimum point on the Paschen curve, Paschen discharge is unlikely (ref. 2).

Paschen discharges are being investigated for Orion's solar arrays, because the incident RCS plume applies a pressure to the array. If this pressure lies in the breakdown region for the voltages on the array, arcing could occur from cell to cell, between interconnects, from spar to cell, and from the array to space. 
During a lunar mission, Orion's main charging environments are low Earth orbit (LEO) and geosynchronous Earth orbit (GEO). In LEO, Orion will be exposed to cold, dense plasma. Plasma interactions are well known in this environment, and assessments performed by Barry Hillard at the NASA Glenn Research Center (GRC) show that arcing in LEO is highly unlikely. In GEO, however, the interaction between Earth's magnetic field and solar storms can cause violent magnetic storms. Orion may experience a charging environment as high as $12,000 \mathrm{eV}$, although it should be noted that the thrusters will most likely not be operating during this time. However, differential charging of Orion's surfaces could occur while passing through GEO on the way to the Moon. Once in deep space, the environment should not charge to more than $200 \mathrm{~V}$. Nevertheless, it is important to assess where the P*D value lies in relation to the Paschen minimum.

It should be noted that Orion solar array photovoltaic cell cover glasses will be coated with a chargedissipating indium tin oxide (ITO) layer to limit voltage excursions to acceptable levels in conditions as harsh as a solar sub-storm. The proper function of the ITO layer, however, could be compromised by plume droplet erosion. If the ITO layer is eroded away, the potential for electrical arcing becomes a real problem. The likelihood of field emission arcing without the presence of neutral species must still be addressed for the situation with a compromised electrostatic discharge layer. Plasma interaction facility ground-based testing with solar cell populated gore coupons is planned to quantify arcing characteristics for this case.

\section{Chemical Contamination}

Orion's RCS utilizes bipropellant thrusters; these thrusters use the hypergolic propellants monomethyl hydrazine (MMH) and dinitrogen tetroxide $\left(\mathrm{N}_{2} \mathrm{O}_{4}\right)$. RCS thrusters usually fire only in short pulses and generally never reach a steady-state operating condition while in pulse-mode. As a result, complete combustion of the propellants does not occur, and the thruster plume contains droplets of uncombusted contaminants whose main constituent is a compound called monomethylhydrazium nitrate $\left(\mathrm{MMH}-\mathrm{HNO}_{3}\right)$ (ref. 3).

If $\mathrm{MMH}-\mathrm{HNO}_{3}$ collects on the surface of a solar array, it will both reflect and absorb a portion of the incident solar energy, effectively preventing it from reaching the solar cells (ref. 3). Additionally, because $\mathrm{MMH}-\mathrm{HNO}_{3}$ absorbs some wavelengths of solar energy, a temperature increase can be induced on the solar array and adversely affect performance (ref. 4).

\section{Thermal Loading}

Solar cell characteristics change with temperature given the same solar input. In general, higher temperatures result in a lower power output. Past UltraFlex wing designs were qualified for maximum temperatures of approximately $160^{\circ} \mathrm{C}$; exceeding this temperature could cause catastrophic damage to the solar arrays. When the thruster plume comes in contact with the SAWs, it can transfer heat to the arrays, effectively increasing their temperatures. For this study, it was assumed that the $160{ }^{\circ} \mathrm{C}$ temperature limit could not be exceeded.

\section{Erosion}

The uncombusted droplets of $\mathrm{MMH}-\mathrm{HNO}_{3}$ can hit the surface of the solar arrays at velocities close to $900 \mathrm{~m} / \mathrm{s}$ (ref. 5). Impacts at these velocities are similar to the impacts of micrometeoroids and orbital debris on solar array surfaces. The main concerns associated with droplet erosion are both the possibility for the removal of solar cell cover glass anti-reflective coating that can lead to wing power loss and the removal of electrostatic discharge coating that can increase the wings' susceptibility to arcing and solar cell damage. Particle impingement angle affects the amount of solar array surface erosion; particles with high angles of incidence to the solar array $\left(>75^{\circ}\right.$ off normal) generally bounce off the array without 
causing damage. Additionally, particles that are more than $30^{\circ}$ to $40^{\circ}$ from the centerline of the thruster plume do not cause damage to the solar array, because the mean diameter and flux of particles are much smaller in this region than near the plume centerline (ref. 6). Current estimates at GRC show that if all the anti-reflective coating $\left(\mathrm{MgF}_{2}\right)$ is eroded away, the solar arrays will experience a 3 percent loss in current.

\section{Force Loading}

In the launch and space environments, force loading on the solar array can be caused by acceleration, mechanical shock, vibration, and acoustic fields. Extreme high and low temperatures can exacerbate the severity of the effects of these problems. Plume impingement induces both mechanical shock and vibration on Orion's SAWs. By definition, mechanical shock is a force that is applied suddenly and for short duration. When the RCS thrusters are fired, the SAWs may initially experience a deformation, and through damped harmonic oscillation, return to zero (ref. 7).

Vibration becomes a problem if the plume induces a vibration on the SAWs equal to the fundamental frequency of the wings. This causes resonance, and if no damping is available, the amplitude of the system continues to increase, risking structural failure (ref. 7). To minimize this risk, it is planned to prohibit RCS pulsed operation at or near the wings' fundamental frequency.

\section{Methods}

\section{Paschen Discharge}

To determine the likelihood of a Paschen discharge on the SAWs, the pressure flux diagram in figure $2^{1}$ was used to estimate pressure across the surface of the SAWs. This diagram is for the worst-case array orientation (aft thrusters firing on SAWs angled $45^{\circ}$ aft).

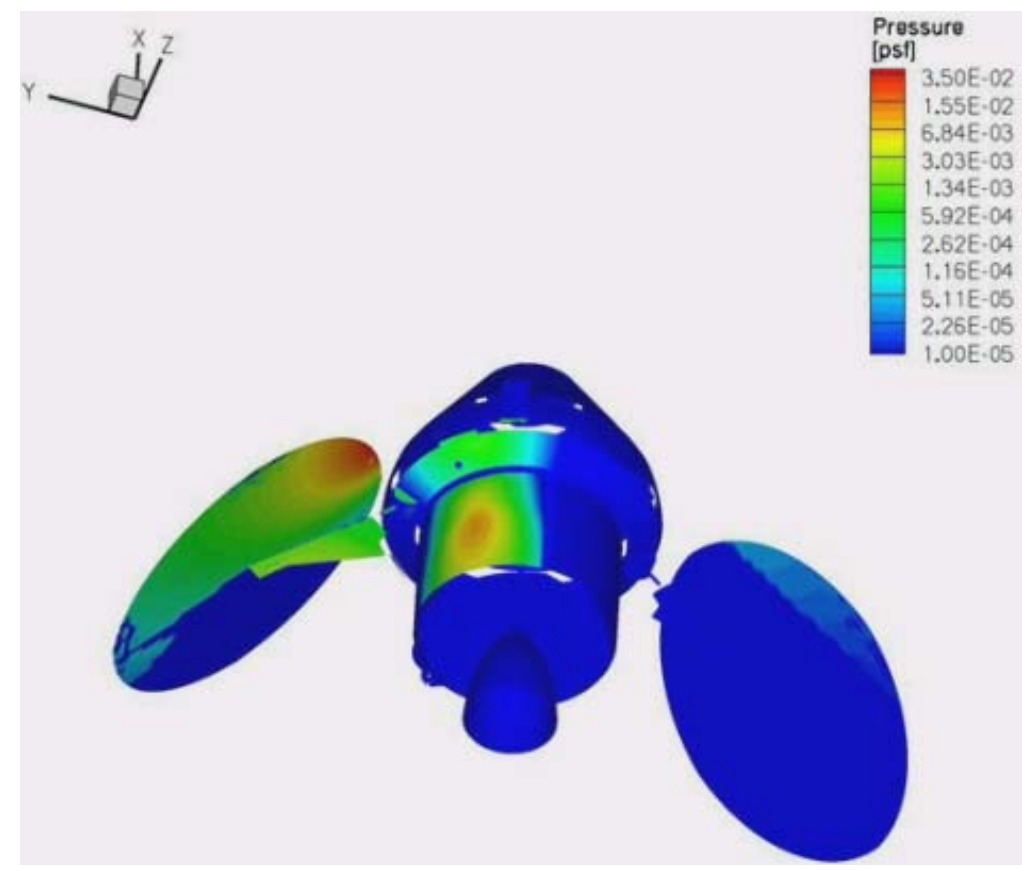

Figure 2.-Worst case pressure loading from one aft-facing thruster. Results from December 2007 version of Plume Impingement Dynamics (PIDYN) model.

\footnotetext{
${ }^{1}$ This and all subsequent PIDYN model outputs generated by Julien du Castel of Lockheed Martin
} 
Two numbers were needed for the assessment: the incident pressure and the electrode spacing on the solar array. The pressure diagram was divided into differing areas of color contours to determine the various pressures incident upon the array. Then, using Dalton's Law of Partial Pressures, the partial pressures of the gases making up the plume were calculated. The mole fractions of the plume gases can be seen in table $1 .^{2}$

TABLE 1.-MOLE FRACTIONS OF GASES IN THRUSTER PLUME

\begin{tabular}{|c|c|}
\hline Component & Mole fraction \\
\hline Diatomic nitrogen & .........0.31049 \\
\hline Diatomic hydrogen & $\ldots 0.27943$ \\
\hline 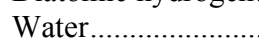 & .... 0.23770 \\
\hline Carbon dioxide....... & .......... 0.14234 \\
\hline Carbon monoxide.. & …….........0.03003 \\
\hline
\end{tabular}

The partial pressures of the plume gases were then multiplied by the distance between the solar cell and the cover glass -5 mils-in order to determine the $\mathrm{P} * \mathrm{D}$ value (see appendix $\mathrm{B}$ ). Then these values were compared with the Paschen curves in appendix A. This method was verified to be correct by Boris Vayner, a plasma physics expert at GRC.

Additionally, the calculation was also performed using the total pressure incident on each color contour, because in reality, the actual $\mathrm{P}^{*} \mathrm{D}$ value will utilize a pressure somewhere between the total incident pressure and the partial pressure of each individual gas.

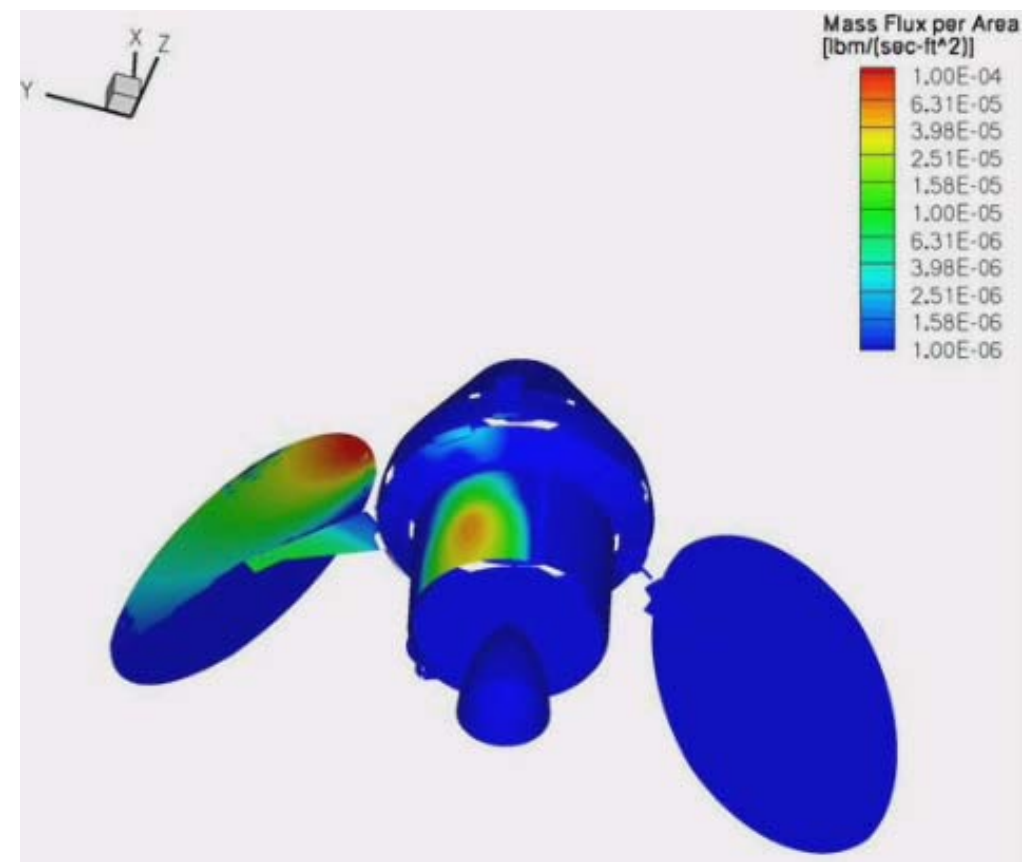

Figure 3.-Worst case mass flux from one aft-facing thruster. Results from December 2007 version of PIDYN model.

${ }^{2}$ Data gathered by Xiaoyen Wang of GRC using the NASA computer program Chemical Equilibrium Applications 


\section{Chemical Contamination}

To assess the amount of contamination on the solar array surfaces, several pieces of data were needed: a mass flux diagram, a plume sticking fraction, and total thruster firing time. The sticking fraction is the amount of plume mass that remains on the solar array divided by the total amount of incident plume mass. Based on the shuttle plume impingement flight experiment contamination studies, a sticking fraction of 0.00001 was used (ref. 8). The diagram of mass flux per area in figure 3 was used.

The RCS thrusters are capable of a total firing time of 7,000 sec, ${ }^{3}$ but in reality, they do not all fire for this amount of time. Additionally, although two aft facing thrusters from each pod are aimed at the arrays, only one of the thrusters should fire at a given time. To estimate the total firing time for the four thrusters that could impinge upon the arrays, it was assumed that a total of $636.4 \mathrm{lb}_{\mathrm{m}}$ of propellant is available to all sixteen RCS thrusters. With four groups of four thrusters distributed evenly around the service module, $159.1 \mathrm{lb}_{\mathrm{m}}$ of propellant is available to each RCS pod. Half of that propellant will be available to the forward thrusters and half to the aft; therefore, $79.5 \mathrm{lb}_{\mathrm{m}}$ of propellant can impinge upon the arrays from one thruster pod. Hence, each thruster pod is capable of firing aft-facing thrusters for $874 \mathrm{sec}$.

By multiplying the mass flux per unit area by the thruster firing time and sticking fraction, the mass of the contaminant per unit area of each color contour on the mass flux diagram was found. Each of these values was multiplied by 2 to take into account that there are two thruster pod clusters that can impinge upon each wing. Using the doubled individual color contour values, an overall wing-averaged contaminant mass per unit area was calculated to be $2.3 \times 10^{-7} \mathrm{~g} / \mathrm{cm}^{2}$. If the contaminant density is assumed to be $1 \mathrm{~g} / \mathrm{mL}$, the thickness of the contamination layer is $23 \AA$.

In order to determine the power loss resulting from the contamination layer, both an equation for

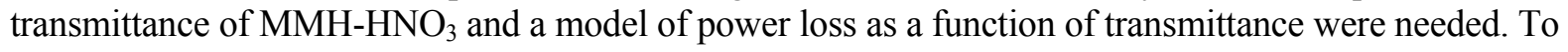
generate an equation for transmittance, the data in figure 4 was used because it shows the transmittance of $\mathrm{MMH}-\mathrm{HNO}_{3}$ as a function of both contaminant mass per unit area and wavelength of incident light (ref. 3).

The contaminant mass per unit area, wavelength, and transmittance data from this graph were put in tabular form and inputted into JMP, a statistics program. Using JMP's nonlinear regression tool and builtin models, an equation for transmittance as a function of wavelength and contaminant mass per unit area was generated where $\sigma 1=1.89354907, \sigma 2=49946.2662$, and $\sigma 3=.91526789$ :

$$
T=\frac{\sigma_{1} \sigma_{3} \lambda}{1+\left(\sigma_{1} \lambda+\sigma_{2} \tau\right)}
$$

A comparison between the experimental data and the equation-generated data is presented in appendix $\mathrm{C}$ and shows that the equation is a good fit for wavelengths of incident light from 300 to $1825 \mathrm{~nm}$ and contamination levels of 0 to $3.3 \times 10^{-3} \mathrm{~g} / \mathrm{cm}^{2}$. It is unknown if the equation is valid for contamination amounts and wavelengths outside these ranges.

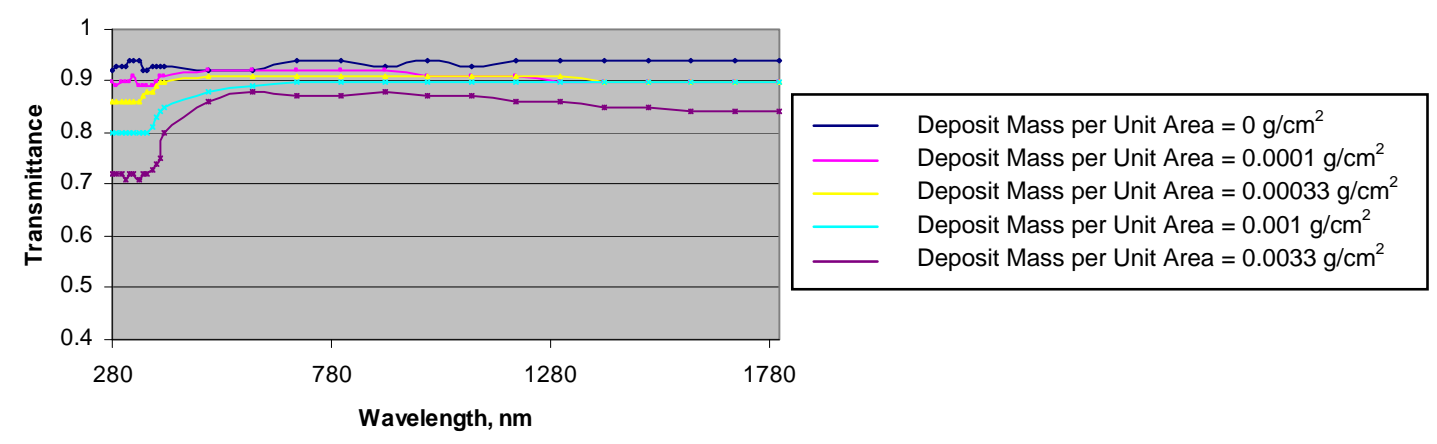

Figure 4.-Transmittance of $\mathrm{MMH}^{-} \mathrm{HNO}_{3}$ as a function of deposit mass per unit area and wavelength. Data is from reference 3.

\footnotetext{
${ }^{3}$ Oral communication with Shane Malone, an Orion Service Module RCS engineer at GRC
} 


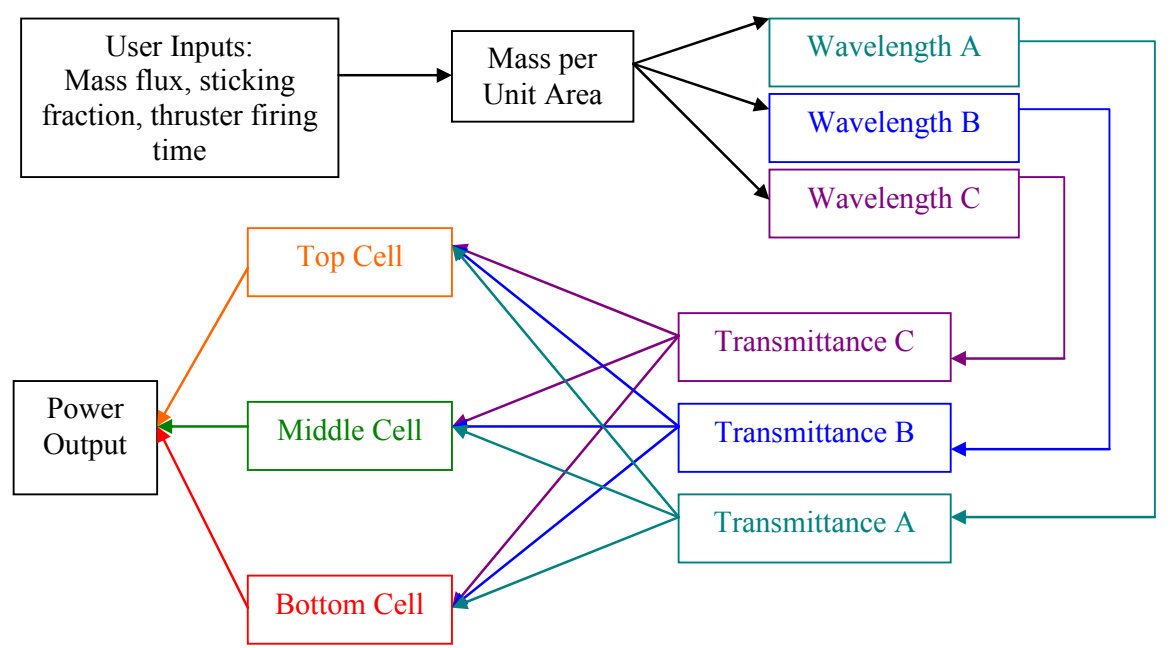

Figure 5.-Flowchart of chemical contamination power loss model.

A model for power loss as a function of transmittance was modified so that mass flux, sticking fraction, and thruster firing time are the model inputs. The flow chart below in figure 5 shows the basic steps the model runs through to determine solar array power loss.

The user enters the input values, and the model generates a contamination mass per unit area. By applying the contamination mass per unit area value over the wavelengths that make up the solar spectrum, transmittance values can be generated. These transmittance values are a function of wavelength and contaminant mass per unit area. Each transmittance value is then applied to the top, middle, and bottom cells of the solar array, and a power output is calculated. The power output is defined as the open circuit voltage multiplied by the short circuit current.

The model goes through this process twice; the first run of the model computes the power output as if there is no contamination. The second run of the model computes the power output resulting from the user inputted contamination data. Finally, the model compares the two power outputs and displays the percentage of power lost due to chemical contamination.

\section{Thermal Loading}

To assess the amount of thermal loading, the diagram of heat flux in figure 6 and a thermal model of Orion's SAWs ${ }^{4}$ were used.

The thermal model is a four-node model that takes into account the temperature gradients across a solar cell that result from differing areas of foam backing on the cells. The four nodes are pointed out in figure 7. The mass, density, and thermo-physical properties of the individual layers of a solar cell are also taken into account. The model outputs the transient temperature across one solar cell. The full array can be generalized by the individual cell if all cells on the array have the same foam coverage. The model allows calculations to be made assuming the plume is incident on either the front or backside of the array.

${ }^{4}$ Developed by GRC summer intern Derek Roberts 


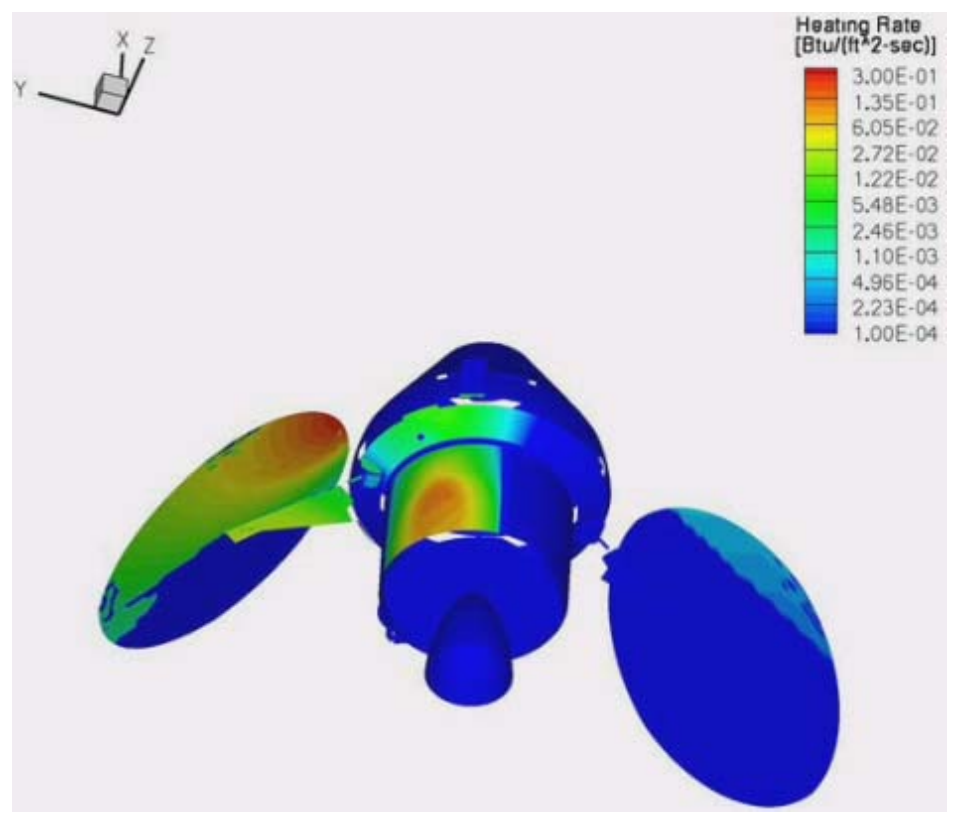

Figure 6.-Worst case heat flux from one aft-facing thruster. Results from December 2007 version of PIDYN model.

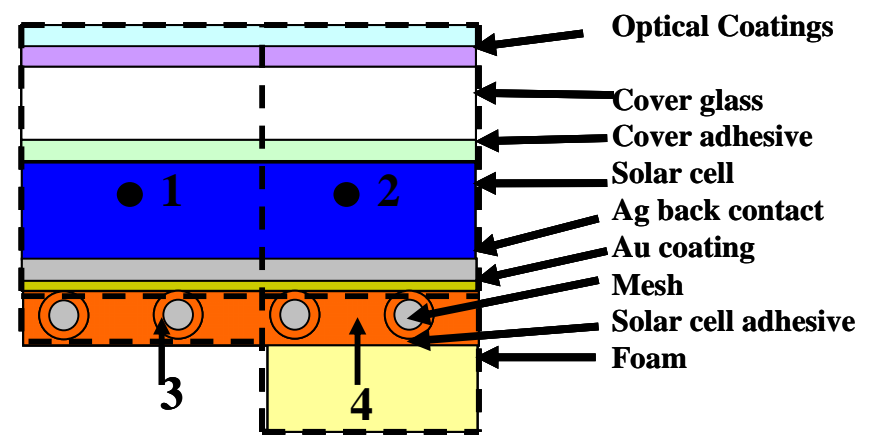

Figure 7.-Cross section of cell with backing. Nodes are labeled.

For the purposes of plume heating assessments, using this model is extremely straightforward. There are two user inputs that deal with thruster induced heating; one input is for the heat flux on the front side of the array, and the second input is for the flux on the backside of the array.

The heat values for each color contour in figure 6 were entered into the thermal model for both the front and backsides of the wings to determine both the maximum temperature reached by each contour and the amount of time the plume must be incident on the array to exceed the temperature limit.

\section{Erosion}

To assess the amount of solar array surface erosion, two main tools were used: a simple CAD model of the Orion service module and a publicly available Boeing model of solar array erosion for a $29-1 b_{f}$ Russian thruster.

The CAD model was created in Google SketchUp. This model was used to measure the angles and distances needed to utilize the Boeing erosion model. 


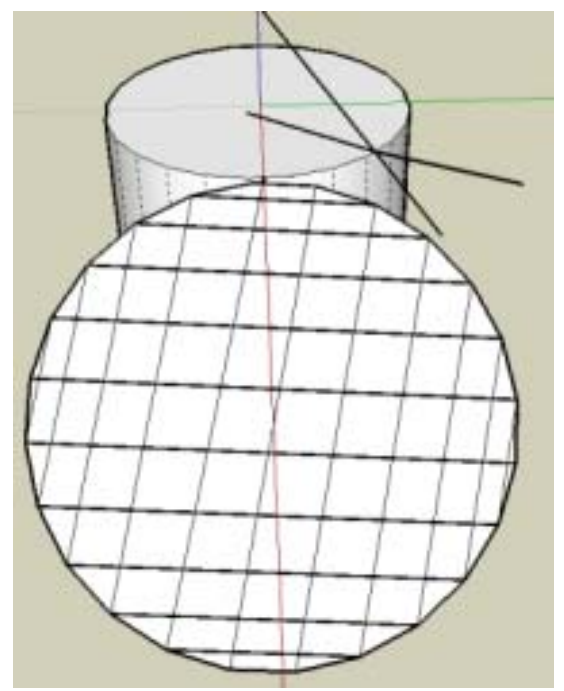

Figure 8.-Solar array sections.

The Boeing model computes the percentage of solar array area damaged as a function of thrust output, $\mathrm{MMH}-\mathrm{HNO}_{3}$ droplet diameter and velocity, angle the droplets make to the normal of the solar array surface, angle from the plume centerline to the damaged point on the array, and range from the thruster to the damaged point on the array (ref. 9). This model implements the velocity model presented in reference 5. Although the erosion model is for a $29-\mathrm{lb}_{\mathrm{f}}$ Russian thruster, the $29-\mathrm{lb}_{\mathrm{f}}$ thruster is similar to the $25-\mathrm{lb}_{\mathrm{f}}$ thrusters used for Orion's RCS, thus the model should give accurate results. A graph of percent area damaged as a function of angle from the plume centerline and range from the thruster was generated using the Boeing model (see appendix D). The Boeing model makes several assumptions. First, the model does not take electrostatic discharge or anti-reflective coatings covering the solar arrays into account; it assumes the solar array surface has no coating. Second, the model assumes all droplets are traveling at their limiting velocities when they strike the SAWs. Third, the model assumes that all droplets strike normal to the solar array surface. These last two assumptions make the model very conservative, because in all likelihood the droplets will be striking the solar arrays at much slower velocities and at high angles of incidence. It is estimated that the model may be conservative by two to three orders of magnitude. ${ }^{5}$

To calculate the percent area damaged, the SAW was divided into eighty-two sections as shown in figure 8 . Each section was assigned an area number. The fraction of total area for each section was calculated by dividing the number of pixels in the section by the total number of pixels making up the SAW. The number of pixels in each section was found using GIMP, a computer graphics program. Both the distance from the nozzle exit to the midpoint of each section and the angle from the plume centerline to the boundary of each section nearest the plume were found using the CAD model. The range and angle values were used in conjunction with the Boeing graph in appendix $\mathrm{D}$ to find the percent damage in each section. For an example of this calculation, see appendix E.

\section{Force Loading}

To calculate the force loading on the SAWs, the impingement pressure diagram in figure 2 was used. Using the basic relationship between pressure, area, and force, the force incident on each color contour of the pressure diagram was calculated, and the pressure diagram was modified to show force values as can be seen in figure 9 .

${ }^{5}$ Oral communication with Paul Boeder of Boeing 


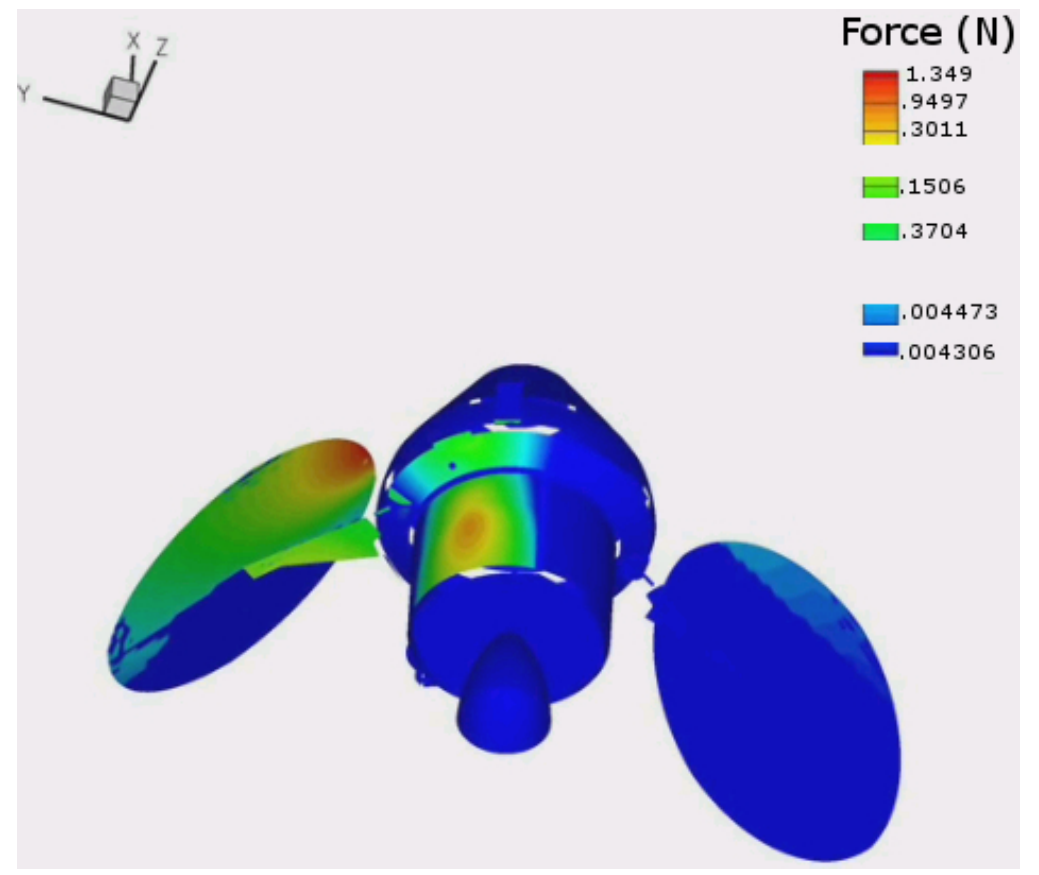

Figure 9.-Worst case force-loading diagram. From one aft-facing thruster.

\section{Results and Conclusions}

\section{Paschen Discharge}

Nitrogen has the smallest Paschen minimum of all the species in the plume with a $\mathrm{P} * \mathrm{D}$ value of 0.5 torr-cm and a breakdown voltage of $200 \mathrm{~V}$. The highest $\mathrm{P} * \mathrm{D}$ value calculated from plume impingement assessments using partial pressures was $9.9 \times 10^{-5}$ torr- $\mathrm{cm}$ and using total pressures was $3.1 \times 10^{-4}$ torr-cm. Based on this comparison of $\mathrm{P}^{*} \mathrm{D}$ values in appendix $\mathrm{B}$ and the Paschen curves in appendix A, it was found that even the highest incident pressures resulted in $\mathrm{P} * \mathrm{D}$ values far to the left of the Paschen minimum for diatomic nitrogen, diatomic hydrogen, and carbon dioxide. It is reasonable to assume that the Paschen curves for water and carbon monoxide will have Paschen minimums near their RCS plume counterparts. Based on these observations, it is safe to assume there is no risk of Paschen discharge between the solar cell and the cover glass.

It is possible, however, that there may be a Paschen discharge between the solar array spars and the solar cells. Figure 10 points out a spar on the UltraFlex SAW. The spars are made of carbon fiber, an electrical conductor. They are attached to the spacecraft, thus they will be at the spacecraft's potential. A quick assessment assuming the absence of a magnetic field and a distance value of $1.5 \mathrm{~m}$ (largest distance between cells and spar on a $5 \mathrm{~m}$ wing) yields $\mathrm{P} * \mathrm{D}$ values in the area of Paschen minimums for all species in the thruster plume. The possibility for spar to solar cell discharge should be assessed in better detail to ascertain whether a Paschen discharge is possible on the solar array. It should be noted that both assessments take into account that there are two RCS thruster pod clusters aimed in the direction of the SAW. 


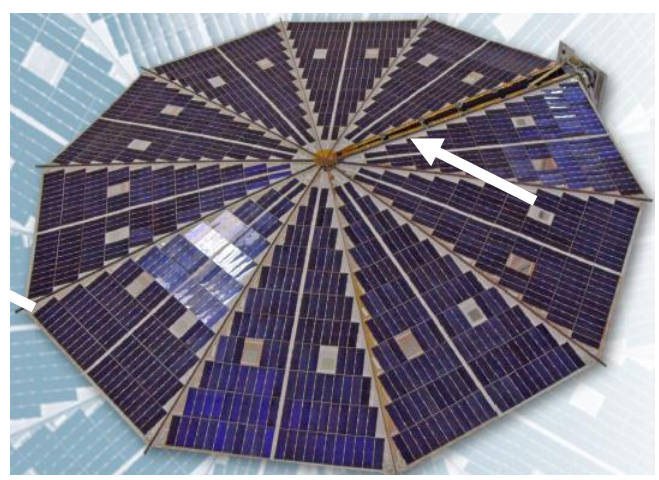

Figure 10.-UltraFlex wing design. The white arrow points to a spar. (Used with permission from ATK.)

\section{Chemical Contamination}

After entering mass fluxes, sticking fraction, and thruster firing time into the chemical contamination power loss model, it was found that there is a 0.0013 percent loss of power from Orion's solar arrays due to chemical contamination. This does not take into account power loss resulting from an increase in temperature on the solar array surface due to the contamination layer absorbing incident heat. Chemical contamination does not pose a serious threat to Orion's power system. This assessment takes into account that there are two RCS thruster pod clusters oriented in the direction of the SAW.

\section{Thermal Loading}

The heat flux values for each color contour in figure 6 were input into the thermal model. The data in tables 2 and 3 summarize the output of the model for front and backside impingement. The values highlighted in red exceed the solar arrays' temperature limit of $160{ }^{\circ} \mathrm{C}$. The final temperature is calculated after $180 \mathrm{sec}$ of continuous thruster firing.

The thermal model outputs show that when one thruster is incident on the array, thermal loading may be a problem for the front side of Orion's solar arrays but not the backside. The length of time the RCS thrusters are fired will determine whether thermal loading will damage the solar arrays. Any wing thermal loading problems will be ameliorated through refined analysis, wing design changes and/or operational measures such as wing keep out zones or thruster continuous on-time limits.

It should be noted that the thermal loading diagram in figure 6 only shows the heat flux from one thruster pod cluster. A mirror image of thermal loading will appear on the other half of the solar array, and in some cases, the incident heat fluxes will stack upon one another. To quickly assess the stacking effect, the heat flux values incident on each color contour of figure 6 were doubled and input into the model. In this conservative case, wing temperature limits were exceeded on both the front and backsides of the arrays.

TABLE 2.-THERMAL MODEL SUMMARY

For front-side impingement

\begin{tabular}{|l|r|r|r|r|r|r|}
\hline Color Contour & $\begin{array}{c}\text { Heat Flux } \\
\mathbf{W} / \mathbf{m}^{2}\end{array}$ & $\begin{array}{c}\text { Node 1 Final } \\
\text { Temp. }\left({ }^{\circ} \mathbf{C}\right)\end{array}$ & $\begin{array}{c}\text { Node 2 Final } \\
\text { Temp }\left({ }^{\circ} \mathbf{C}\right)\end{array}$ & $\begin{array}{c}\text { Node 3 Final } \\
\left.\text { Temp ( }{ }^{\circ} \mathbf{C}\right)\end{array}$ & $\begin{array}{c}\text { Node 4 Final } \\
\text { Temp }\left({ }^{\circ} \mathbf{C}\right)\end{array}$ & $\begin{array}{c}\text { Time to Exceed } \\
\text { Temp. Limit (s) }\end{array}$ \\
\hline Dark Red & 3404.15 & 247 & 256 & 241 & 255 & 13 \\
\hline Light Red & 1531.87 & 186 & 191 & 183 & 190 & 33 \\
\hline Orange & 1109.18 & 168 & 172 & 166 & 171 & 50 \\
\hline Yellow & 686.50 & 148 & 150 & 146 & 149 & $\mathrm{~N} / \mathrm{A}$ \\
\hline Yellow-green & 308.64 & 126 & 127 & 125 & 126 & $\mathrm{~N} / \mathrm{A}$ \\
\hline Green & 62.18 & 110 & 109 & 110 & 109 & $\mathrm{~N} / \mathrm{A}$ \\
\hline Blue & 1.13 & 106 & 105 & 105 & 105 & $\mathrm{~N} / \mathrm{A}$ \\
\hline Teal & 5.63 & 106 & 105 & 106 & 105 & $\mathrm{~N} / \mathrm{A}$ \\
\hline
\end{tabular}


TABLE 3.-THERMAL MODEL SUMMARY

For backside impingement

\begin{tabular}{|l|r|r|r|r|r|r|}
\hline Color Contour & $\begin{array}{c}\text { Heat Flux } \\
\mathbf{W} / \mathbf{m}^{\mathbf{2}}\end{array}$ & $\begin{array}{c}\text { Node 1 Final } \\
\text { Temp. }\left({ }^{\circ} \mathbf{C}\right)\end{array}$ & $\begin{array}{c}\text { Node 2 Final } \\
\text { Temp }\left({ }^{\circ} \mathbf{C}\right)\end{array}$ & $\begin{array}{c}\text { Node 3 Final } \\
\text { Temp }\left({ }^{\circ} \mathbf{C}\right)\end{array}$ & $\begin{array}{c}\text { Node 4 Final } \\
\text { Temp }\left({ }^{\circ} \mathbf{C}\right)\end{array}$ & $\begin{array}{c}\text { Time to Exceed } \\
\text { Temp. Limit (s) }\end{array}$ \\
\hline Dark Red & 3404.15 & 147 & 134 & 152 & 134 & N/A \\
\hline Light Red & 1531.87 & 126 & 119 & 128 & 119 & N/A \\
\hline Orange & 1109.18 & 120 & 115 & 122 & 115 & N/A \\
\hline Yellow & 686.50 & 115 & 111 & 116 & 111 & $\mathrm{~N} / \mathrm{A}$ \\
\hline Yellow-green & 308.64 & 109 & 107 & 110 & 107 & $\mathrm{~N} / \mathrm{A}$ \\
\hline Green & 62.18 & 106 & 105 & 106 & 105 & $\mathrm{~N} / \mathrm{A}$ \\
\hline Blue & 1.13 & 105 & 104 & 105 & 104 & $\mathrm{~N} / \mathrm{A}$ \\
\hline Teal & 5.63 & 105 & 104 & 105 & 104 & $\mathrm{~N} / \mathrm{A}$ \\
\hline
\end{tabular}

\section{Erosion}

By using Boeing's erosion model in appendix D and a simple CAD model of Orion, the percent area damaged by plume impingement was calculated to be $8.3 \times 10^{-5}$ percent. This value is likely high because the Boeing erosion model is conservative by two to three orders of magnitude. Keeping in mind that there is a 3 percent loss of power if 100 percent of the solar array is damaged, there will only be a $2.5 \times 10^{-6}$ percent loss in power associated with the $8.3 \times 10^{-5}$ percent area damaged. It is very unlikely that erosion will be a problem for Orion's SAWs. This assessment takes into account that there are two RCS thruster pod clusters aimed in the direction of the SAW.

\section{Force Loading}

By using the generated force-loading diagram in figure 9 , moments in the $\mathrm{x}$ and $\mathrm{y}$ directions were calculated. The "center of force" of each color contour was estimated, and the moment arm from each "center of force" to the boom (represented by the origin of the coordinate axes drawn) was found in the $\mathrm{x}$ and y directions. These moment arms were then multiplied by the force applied to each color contour to find the moment. The results are presented in table 4. It should be noted that these moment values are estimations. Because of the orientation of Orion in the force-loading diagram, it was difficult to take moment arm measurements.

TABLE 4.-MOMENT CALCULATIONS

\begin{tabular}{|r|r|r|r|r|}
\hline Force (N) & X Moment Arm (m) & Y Moment Arm $(\mathbf{m})$ & X Moment $\left(\mathbf{N}^{*} \mathbf{m}\right)$ & Y Moment $\left(\mathbf{N}^{*} \mathbf{m}\right)$ \\
\hline 2.698 & 1.16 & 0.58 & 3.13 & 1.565 \\
\hline 1.8994 & 0.928 & 1.16 & 1.76 & 2.20 \\
\hline 0.6022 & 1.16 & 1.74 & 0.70 & 1.048 \\
\hline 0.7408 & 0.58 & 2.9 & 0.43 & 2.15 \\
\hline 0.008946 & 0.348 & -4.872 & 0.0031 & -0.044 \\
\hline 0.008612 & 0.464 & -3.13 & 0.0040 & -0.027 \\
\hline
\end{tabular}

These moments are negligible when compared to the 1-g loads experienced during ground testing and the 2-g to 3-g inertial deployed loads during the trans-lunar injection burn. Therefore, force loading is not a problem for Orion's SAWs. This assessment takes into account the fact that there are two RCS thruster pod clusters aimed in the direction of the SAW. 


\section{Concluding Remarks}

Based on the simple engineering assessments presented, RCS thruster plume impingement may only be a problem for thermal loading and Paschen discharge. If the thrusters fire for too long, temperature limits on the SAWs will be exceeded. An in-depth analysis is needed to determine if there is a possibility for spar to solar cell Paschen discharge; preliminary estimates suggest it may be a problem. Chemical contamination and surface erosion were the only other areas that showed any evidence of potential plume impingement problems, and the power losses associated with both were well below Orion's assumed plume impingement induced power loss budget of 2 percent. Additionally, all assessments were made for the worst case orientation of the SAWs (wings angled $45^{\circ}$ aft); in reality, the wings will not always be in this orientation when the thrusters fire, so plume impingement effects will likely be less than what is predicted in this report. 



\section{Appendix A-Paschen Curves (Ref. 2)}

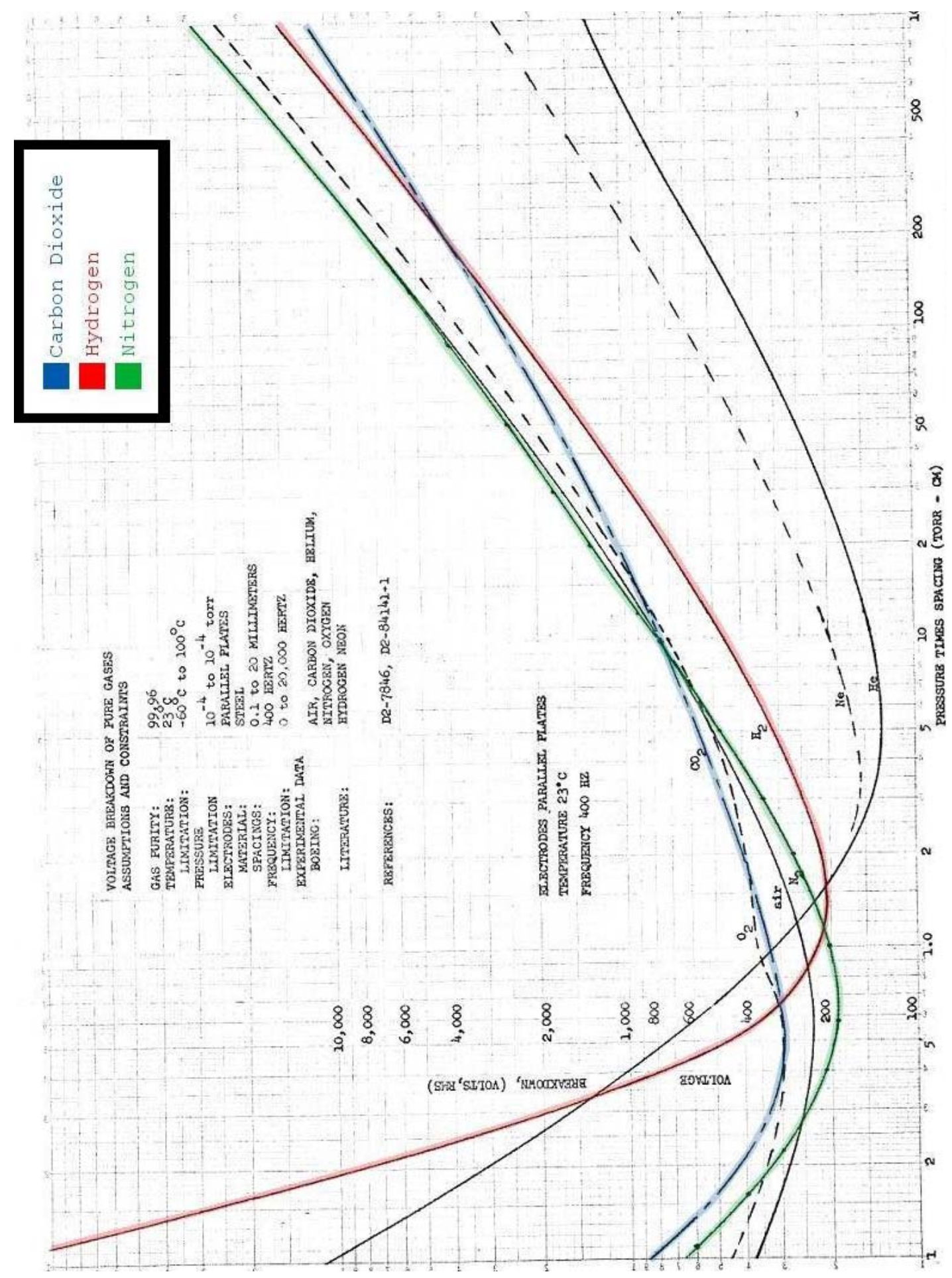





\section{Appendix B-P*D Calculations}

\section{B.1 Partial Pressure Calculations}

\begin{tabular}{|c|c|c|c|c|}
\hline \multirow{2}{*}{$\begin{array}{l}\text { Color Contour } \\
\text { Red }\end{array}$} & \multicolumn{4}{|c|}{ Partial Pressure (torr) } \\
\hline & Carbon Dioxide & Hydrogen & Water & Nitrogen \\
\hline & Pressure & Pressure & Pressure & Pressure \\
\hline & 1.79E-03 & 3.51E-03 & 2.99E-03 & 3.90E-03 \\
\hline$P * D($ torr*cm) & 4.54E-05 & 8.92E-05 & 7.59E-05 & 9.91E-05 \\
\hline Color Contour & \multicolumn{4}{|c|}{ Partial Pressure (torr) } \\
\hline \multirow[t]{3}{*}{ Orange } & Carbon Dioxide & Hydrogen & Water & Nitrogen \\
\hline & Pressure & Pressure & Pressure & Pressure \\
\hline & 7.92E-04 & 1.56E-03 & $1.32 \mathrm{E}-03$ & $1.73 \mathrm{E}-03$ \\
\hline$P * D\left(\right.$ torr $\left.^{*} \mathrm{~cm}\right)$ & 2.01E-05 & 3.95E-05 & 3.36E-05 & 4.39E-05 \\
\hline Color Contour & \multicolumn{4}{|c|}{ Partial Pressure (torr) } \\
\hline \multirow[t]{3}{*}{ Yellow } & Carbon Dioxide & Hydrogen & Water & Nitrogen \\
\hline & Pressure & Pressure & Pressure & Pressure \\
\hline & $3.50 \mathrm{E}-04$ & 6.86E-04 & 5.84E-04 & 7.63E-04 \\
\hline$P * D($ torr*cm) & 8.88E-06 & 1.74E-05 & 1.48E-05 & 1.94E-05 \\
\hline Color Contour & \multicolumn{4}{|c|}{ Partial Pressure (torr) } \\
\hline \multirow[t]{3}{*}{ Dark green } & Carbon Dioxide & Hydrogen & Water & Nitrogen \\
\hline & Pressure & Pressure & Pressure & Pressure \\
\hline & 3.03E-05 & 5.94E-05 & 5.05E-05 & 6.60E-05 \\
\hline P*D (torr*cm) & 7.69E-07 & 1.51E-06 & $1.28 E-06$ & 1.68E-06 \\
\hline Color Contour & \multicolumn{4}{|c|}{ Partial Pressure (torr) } \\
\hline \multirow[t]{3}{*}{ Bright green } & Carbon Dioxide & Hydrogen & Water & Nitrogen \\
\hline & Pressure & Pressure & Pressure & Pressure \\
\hline & $1.55 \mathrm{E}-04$ & 3.04E-04 & 2.59E-04 & 3.38E-04 \\
\hline$P * D$ (torr*cm) & 3.93E-06 & 7.72E-06 & 6.57E-06 & 8.58E-06 \\
\hline Color Contour & \multicolumn{4}{|c|}{ Partial Pressure (torr) } \\
\hline \multirow[t]{3}{*}{ Light Blue } & Carbon Dioxide & Hydrogen & Water & Nitrogen \\
\hline & Pressure & Pressure & Pressure & Pressure \\
\hline & 2.61E-06 & 5.13E-06 & 4.36E-06 & 5.70E-06 \\
\hline P*D (torr*cm) & 6.63E-08 & $1.30 \mathrm{E}-07$ & 1.11E-07 & 1.45E-07 \\
\hline Color Contour & \multicolumn{4}{|c|}{ Partial Pressure (torr) } \\
\hline \multirow[t]{3}{*}{ Dark Blue } & Carbon Dioxide & Hydrogen & Water & Nitrogen \\
\hline & Pressure & Pressure & Pressure & Pressure \\
\hline & $5.11 \mathrm{E}-07$ & $1.00 \mathrm{E}-06$ & 8.54E-07 & $1.12 \mathrm{E}-06$ \\
\hline$P * D($ torr*cm) & $1.30 \mathrm{E}-08$ & 2.55E-08 & 2.17E-08 & 2.83E-08 \\
\hline
\end{tabular}

\section{B.2 Total Pressure Calculations}

\begin{tabular}{|l|r|r|r|}
\hline $\begin{array}{c}\text { Color Zone on } \\
\text { Pressure Diagram }\end{array}$ & $\begin{array}{c}\text { Total Pressure } \\
\text { (torr) }\end{array}$ & $\begin{array}{c}\text { Electrode Spacing } \\
\text { "D" (cm) }\end{array}$ & $\begin{array}{c}P^{*} \mathbf{D} \\
\text { (torr*cm) }\end{array}$ \\
\hline Red & $2.51 \mathrm{E}-02$ & 0.0127 & $3.19 \mathrm{E}-04$ \\
\hline Orange & $1.11 \mathrm{E}-02$ & 0.0127 & $1.41 \mathrm{E}-04$ \\
\hline Yellow & $4.91 \mathrm{E}-03$ & 0.0127 & $6.24 \mathrm{E}-05$ \\
\hline Dark green & $4.25 \mathrm{E}-04$ & 0.0127 & $5.40 \mathrm{E}-06$ \\
\hline Bright green & $2.18 \mathrm{E}-03$ & 0.0127 & $2.76 \mathrm{E}-05$ \\
\hline Light Blue & $3.67 \mathrm{E}-05$ & 0.0127 & $4.66 \mathrm{E}-07$ \\
\hline Dark Blue & $7.18 \mathrm{E}-06$ & 0.0127 & $9.12 \mathrm{E}-08$ \\
\hline
\end{tabular}





\section{Appendix C-Transmittance Model Validation}

\begin{tabular}{|c|c|c|c|c|}
\hline \multicolumn{2}{|c|}{ Input conditions } & \multirow{2}{*}{$\frac{\text { Experimental }}{\text { Transmittance }}$} & \multirow{2}{*}{$\frac{\text { Model }}{\text { Transmittance }}$} & \multirow[b]{2}{*}{$\begin{array}{c}\text { Error } \\
(\%)\end{array}$} \\
\hline $\begin{array}{l}\text { Wavelength } \\
(\mathrm{nm})\end{array}$ & $\begin{array}{l}\text { Contaminant mass } \\
\text { per unit area }\left(\mathrm{g} / \mathrm{cm}^{2}\right)\end{array}$ & & & \\
\hline 280 & 0 & 0.92 & 0.91 & 0.702 \\
\hline 290 & 0 & 0.93 & 0.91 & 1.763 \\
\hline 300 & 0 & 0.93 & 0.91 & 1.757 \\
\hline 310 & 0 & 0.93 & 0.91 & 1.751 \\
\hline 320 & 0 & 0.94 & 0.91 & 2.792 \\
\hline 330 & 0 & 0.94 & 0.91 & 2.787 \\
\hline 340 & 0 & 0.94 & 0.91 & 2.782 \\
\hline 350 & 0 & 0.92 & 0.91 & 0.664 \\
\hline 360 & 0 & 0.92 & 0.91 & 0.660 \\
\hline 370 & 0 & 0.93 & 0.91 & 1.724 \\
\hline 380 & 0 & 0.93 & 0.91 & 1.721 \\
\hline 390 & 0 & 0.93 & 0.91 & 1.717 \\
\hline 400 & 0 & 0.93 & 0.91 & 1.714 \\
\hline 500 & 0 & 0.92 & 0.91 & 0.619 \\
\hline 600 & 0 & 0.92 & 0.91 & 0.602 \\
\hline 700 & 0 & 0.94 & 0.91 & 2.704 \\
\hline 800 & 0 & 0.94 & 0.91 & 2.695 \\
\hline 900 & 0 & 0.93 & 0.91 & 1.642 \\
\hline 1000 & 0 & 0.94 & 0.91 & 2.682 \\
\hline 1100 & 0 & 0.93 & 0.91 & 1.631 \\
\hline 1200 & 0 & 0.94 & 0.91 & 2.674 \\
\hline 1300 & 0 & 0.94 & 0.91 & 2.671 \\
\hline 1400 & 0 & 0.94 & 0.91 & 2.668 \\
\hline 1500 & 0 & 0.94 & 0.91 & 2.665 \\
\hline 1600 & 0 & 0.94 & 0.91 & 2.663 \\
\hline 1700 & 0 & 0.94 & 0.91 & 2.661 \\
\hline 1800 & 0 & 0.94 & 0.91 & 2.660 \\
\hline 280 & 0.0001 & 0.9 & 0.91 & -0.559 \\
\hline 290 & 0.0001 & 0.89 & 0.91 & -1.729 \\
\hline 300 & 0.0001 & 0.9 & 0.91 & -0.634 \\
\hline 310 & 0.0001 & 0.9 & 0.91 & -0.668 \\
\hline 320 & 0.0001 & 0.9 & 0.91 & -0.700 \\
\hline 330 & 0.0001 & 0.91 & 0.91 & 0.377 \\
\hline 340 & 0.0001 & 0.89 & 0.91 & -1.890 \\
\hline 350 & 0.0001 & 0.89 & 0.91 & -1.917 \\
\hline 360 & 0.0001 & 0.89 & 0.91 & -1.943 \\
\hline 370 & 0.0001 & 0.89 & 0.91 & -1.967 \\
\hline 380 & 0.0001 & 0.9 & 0.91 & -0.856 \\
\hline 390 & 0.0001 & 0.91 & 0.91 & 0.231 \\
\hline 400 & 0.0001 & 0.91 & 0.91 & 0.211 \\
\hline 500 & 0.0001 & 0.92 & 0.91 & 1.140 \\
\hline 600 & 0.0001 & 0.92 & 0.91 & 1.037 \\
\hline 700 & 0.0001 & 0.92 & 0.91 & 0.962 \\
\hline 800 & 0.0001 & 0.92 & 0.91 & 0.906 \\
\hline 900 & 0.0001 & 0.92 & 0.91 & 0.863 \\
\hline 1000 & 0.0001 & 0.91 & 0.91 & -0.261 \\
\hline 1100 & 0.0001 & 0.91 & 0.91 & -0.290 \\
\hline 1200 & 0.0001 & 0.91 & 0.91 & -0.314 \\
\hline
\end{tabular}




\begin{tabular}{|c|c|c|c|c|}
\hline \multicolumn{2}{|c|}{ Input conditions } & \multirow{2}{*}{$\frac{\text { Experimental }}{\text { Transmittance }}$} & \multirow{2}{*}{$\frac{\text { Model }}{\text { Transmittance }}$} & \multirow[b]{2}{*}{$\begin{array}{l}\text { Error } \\
(\%)\end{array}$} \\
\hline $\begin{array}{l}\text { Wavelength } \\
(\mathrm{nm})\end{array}$ & $\begin{array}{l}\text { Contaminant mass } \\
\text { per unit area }\left(\mathrm{g} / \mathrm{cm}^{2}\right)\end{array}$ & & & \\
\hline 1300 & 0.0001 & 0.9 & 0.91 & -1.449 \\
\hline 1400 & 0.0001 & 0.9 & 0.91 & -1.467 \\
\hline 1500 & 0.0001 & 0.9 & 0.91 & -1.482 \\
\hline 1600 & 0.0001 & 0.9 & 0.91 & -1.496 \\
\hline 1700 & 0.0001 & 0.9 & 0.91 & -1.507 \\
\hline 1800 & 0.0001 & 0.9 & 0.91 & -1.518 \\
\hline 280 & 0.00033 & 0.86 & 0.89 & -3.029 \\
\hline 290 & 0.00033 & 0.86 & 0.89 & -3.143 \\
\hline 300 & 0.00033 & 0.86 & 0.89 & -3.249 \\
\hline 310 & 0.00033 & 0.86 & 0.89 & -3.349 \\
\hline 320 & 0.00033 & 0.86 & 0.89 & -3.442 \\
\hline 330 & 0.00033 & 0.86 & 0.89 & -3.530 \\
\hline 340 & 0.00033 & 0.86 & 0.89 & -3.613 \\
\hline 350 & 0.00033 & 0.87 & 0.89 & -2.499 \\
\hline 360 & 0.00033 & 0.88 & 0.89 & -1.407 \\
\hline 370 & 0.00033 & 0.88 & 0.89 & -1.476 \\
\hline 380 & 0.00033 & 0.89 & 0.89 & -0.400 \\
\hline 390 & 0.00033 & 0.9 & 0.89 & 0.655 \\
\hline 400 & 0.00033 & 0.9 & 0.89 & 0.598 \\
\hline 500 & 0.00033 & 0.91 & 0.90 & 1.245 \\
\hline 600 & 0.00033 & 0.91 & 0.90 & 0.945 \\
\hline 700 & 0.00033 & 0.91 & 0.90 & 0.730 \\
\hline 800 & 0.00033 & 0.91 & 0.90 & 0.569 \\
\hline 900 & 0.00033 & 0.91 & 0.91 & 0.442 \\
\hline 1000 & 0.00033 & 0.91 & 0.91 & 0.341 \\
\hline 1100 & 0.00033 & 0.91 & 0.91 & 0.258 \\
\hline 1200 & 0.00033 & 0.91 & 0.91 & 0.189 \\
\hline 1300 & 0.00033 & 0.91 & 0.91 & 0.130 \\
\hline 1400 & 0.00033 & 0.9 & 0.91 & -1.030 \\
\hline 1500 & 0.00033 & 0.9 & 0.91 & -1.074 \\
\hline 1600 & 0.00033 & 0.9 & 0.91 & -1.113 \\
\hline 1700 & 0.00033 & 0.9 & 0.91 & -1.147 \\
\hline 1800 & 0.00033 & 0.9 & 0.91 & -1.177 \\
\hline 280 & 0.001 & 0.8 & 0.84 & -4.379 \\
\hline 290 & 0.001 & 0.8 & 0.84 & -4.695 \\
\hline 300 & 0.001 & 0.8 & 0.84 & -4.992 \\
\hline 310 & 0.001 & 0.8 & 0.84 & -5.272 \\
\hline 320 & 0.001 & 0.8 & 0.84 & -5.535 \\
\hline 330 & 0.001 & 0.8 & 0.85 & -5.784 \\
\hline 340 & 0.001 & 0.8 & 0.85 & -6.019 \\
\hline 350 & 0.001 & 0.8 & 0.85 & -6.241 \\
\hline 360 & 0.001 & 0.8 & 0.85 & -6.453 \\
\hline 370 & 0.001 & 0.81 & 0.85 & -5.336 \\
\hline 380 & 0.001 & 0.83 & 0.85 & -2.982 \\
\hline 390 & 0.001 & 0.84 & 0.86 & -1.929 \\
\hline 400 & 0.001 & 0.85 & 0.86 & -0.892 \\
\hline 500 & 0.001 & 0.88 & 0.87 & 1.303 \\
\hline 600 & 0.001 & 0.89 & 0.88 & 1.575 \\
\hline 700 & 0.001 & 0.9 & 0.88 & 2.068 \\
\hline 800 & 0.001 & 0.9 & 0.89 & 1.612 \\
\hline
\end{tabular}




\begin{tabular}{|c|c|c|c|c|}
\hline \multicolumn{2}{|c|}{ Input conditions } & \multirow{2}{*}{$\frac{\text { Experimental }}{\text { Transmittance }}$} & \multirow{2}{*}{$\frac{\text { Model }}{\text { Transmittance }}$} & \multirow[b]{2}{*}{$\begin{array}{c}\text { Error } \\
(\%)\end{array}$} \\
\hline $\begin{array}{l}\text { Wavelength } \\
(\mathrm{nm})\end{array}$ & $\begin{array}{l}\text { Contaminant mass } \\
\text { per unit area }\left(\mathrm{g} / \mathrm{cm}^{2}\right)\end{array}$ & & & \\
\hline 900 & 0.001 & 0.9 & 0.89 & 1.255 \\
\hline 1000 & 0.001 & 0.9 & 0.89 & 0.968 \\
\hline 1100 & 0.001 & 0.9 & 0.89 & 0.732 \\
\hline 1200 & 0.001 & 0.9 & 0.90 & 0.534 \\
\hline 1300 & 0.001 & 0.9 & 0.90 & 0.366 \\
\hline 1400 & 0.001 & 0.9 & 0.90 & 0.221 \\
\hline 1500 & 0.001 & 0.9 & 0.90 & 0.096 \\
\hline 1600 & 0.001 & 0.9 & 0.90 & -0.015 \\
\hline 1700 & 0.001 & 0.9 & 0.90 & -0.112 \\
\hline 1800 & 0.001 & 0.9 & 0.90 & -0.199 \\
\hline 280 & 0.0033 & 0.72 & 0.70 & 3.165 \\
\hline 290 & 0.0033 & 0.72 & 0.70 & 2.363 \\
\hline 300 & 0.0033 & 0.72 & 0.71 & 1.602 \\
\hline 310 & 0.0033 & 0.71 & 0.71 & -0.516 \\
\hline 320 & 0.0033 & 0.72 & 0.72 & 0.193 \\
\hline 330 & 0.0033 & 0.72 & 0.72 & -0.461 \\
\hline 340 & 0.0033 & 0.71 & 0.73 & -2.508 \\
\hline 350 & 0.0033 & 0.72 & 0.73 & -1.680 \\
\hline 360 & 0.0033 & 0.72 & 0.74 & -2.248 \\
\hline 370 & 0.0033 & 0.73 & 0.74 & -1.383 \\
\hline 380 & 0.0033 & 0.74 & 0.74 & -0.520 \\
\hline 390 & 0.0033 & 0.75 & 0.75 & 0.342 \\
\hline 400 & 0.0033 & 0.8 & 0.75 & 6.140 \\
\hline 500 & 0.0033 & 0.86 & 0.78 & 9.435 \\
\hline 600 & 0.0033 & 0.88 & 0.80 & 9.239 \\
\hline 700 & 0.0033 & 0.87 & 0.81 & 6.495 \\
\hline 800 & 0.0033 & 0.87 & 0.82 & 5.177 \\
\hline 900 & 0.0033 & 0.88 & 0.83 & 5.215 \\
\hline 1000 & 0.0033 & 0.87 & 0.84 & 3.268 \\
\hline 1100 & 0.0033 & 0.87 & 0.85 & 2.555 \\
\hline 1200 & 0.0033 & 0.86 & 0.85 & 0.812 \\
\hline 1300 & 0.0033 & 0.86 & 0.86 & 0.290 \\
\hline 1400 & 0.0033 & 0.85 & 0.86 & -1.340 \\
\hline 1500 & 0.0033 & 0.85 & 0.86 & -1.739 \\
\hline 1600 & 0.0033 & 0.84 & 0.87 & -3.306 \\
\hline 1700 & 0.0033 & 0.84 & 0.87 & -3.623 \\
\hline 1800 & 0.0033 & 0.84 & 0.87 & -3.905 \\
\hline & & & Average: & -0.065 \\
\hline
\end{tabular}





\section{Appendix D-Boeing Erosion Model (Ref. 9)}

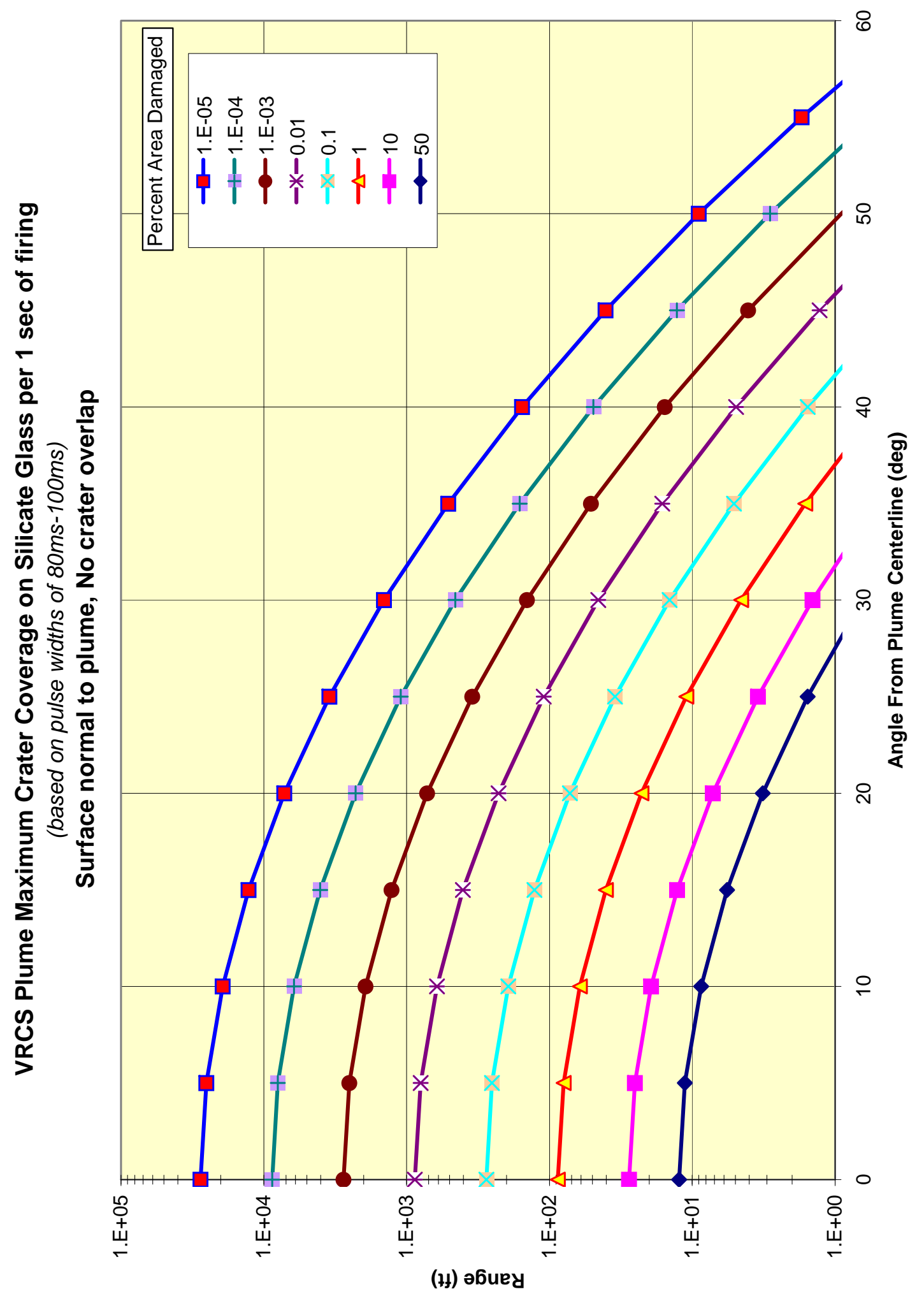





\section{Appendix E-Sample Erosion Calculator}

\begin{tabular}{|c|c|c|c|c|c|c|c|c|c|c|}
\hline $\begin{array}{c}\text { Area of } \\
\text { Array }\left(\mathrm{m}^{2}\right)\end{array}$ & Area \# & $\begin{array}{l}\text { Pixel } \\
\text { Area }\end{array}$ & $\begin{array}{c}\text { Fraction of } \\
\text { Total Area }\end{array}$ & \begin{tabular}{|c|} 
Range \\
$(\mathrm{m})$
\end{tabular} & \begin{tabular}{|c|} 
Range \\
$(\mathrm{ft})$
\end{tabular} & $\begin{array}{c}\text { Angle } \\
\left({ }^{\circ}\right)\end{array}$ & $\begin{array}{l}\text { Fraction } \\
\text { Damaged }\end{array}$ & $\begin{array}{c}\text { Damaged } \\
\text { Area }\end{array}$ & $\begin{array}{c}\text { Total Damaged } \\
\text { Area }\left(\mathrm{m}^{2}\right)\end{array}$ & 2.22E-05 \\
\hline 26.7864756 & 1 & 247 & $2.05 \mathrm{E}-03$ & 1.90 & 6.23 & 53.6 & 1.00E-07 & $5.49 \mathrm{E}-09$ & \multirow{2}{*}{$\begin{array}{c}\text { Percent of Solar } \\
\text { Array }\end{array}$} & \multirow{2}{*}{ 8.30E-05 } \\
\hline & 2 & 401 & $3.33 \mathrm{E}-03$ & 1.43 & 4.69 & 51.6 & $1.00 \mathrm{E}-06$ & $8.92 \mathrm{E}-08$ & & \\
\hline & 3 & 194 & $1.61 \mathrm{E}-03$ & 1.15 & 3.77 & 51 & 1.00E-07 & 4.31E-09 & \multirow{2}{*}{$\begin{array}{c}\text { Percent Power } \\
\text { Loss }\end{array}$} & \multirow{2}{*}{$2.49 \mathrm{E}-06$} \\
\hline & 4 & 375 & $3.11 \mathrm{E}-03$ & 2.75 & 9.02 & 53.1 & $0.00 \mathrm{E}+00$ & $0.00 \mathrm{E}+00$ & & \\
\hline & 5 & 1144 & $9.49 \mathrm{E}-03$ & 2.23 & 7.32 & 53.6 & $0.00 \mathrm{E}+00$ & $0.00 \mathrm{E}+00$ & & \\
\hline & 6 & 891 & $7.40 \mathrm{E}-03$ & 1.66 & 5.45 & 51.6 & 1.00E-07 & $1.98 \mathrm{E}-08$ & & \\
\hline & 7 & 1074 & $8.91 \mathrm{E}-03$ & 1.30 & 4.27 & 51 & $1.00 \mathrm{E}-07$ & $2.39 \mathrm{E}-08$ & & \\
\hline & 75 & 674 & 5.59E-03 & 6.62 & 21.72 & 53.6 & $0.00 \mathrm{E}+00$ & $0.00 \mathrm{E}+00$ & & \\
\hline & 76 & 1543 & $1.28 \mathrm{E}-02$ & 6.34 & 20.80 & 51.6 & $0.00 \mathrm{E}+00$ & $0.00 \mathrm{E}+00$ & & \\
\hline & 77 & 1531 & $1.27 \mathrm{E}-02$ & 6.17 & 20.24 & 51 & $0.00 \mathrm{E}+00$ & $0.00 \mathrm{E}+00$ & & \\
\hline & 78 & 1458 & $1.21 \mathrm{E}-02$ & 6.10 & 20.01 & 51.1 & $0.00 \mathrm{E}+00$ & $0.00 \mathrm{E}+00$ & & \\
\hline & 79 & 609 & $5.05 E-03$ & 6.04 & 19.82 & 50.1 & $0.00 \mathrm{E}+00$ & $0.00 \mathrm{E}+00$ & & \\
\hline & 80 & 367 & $3.05 \mathrm{E}-03$ & 6.60 & 21.65 & 51.6 & $0.00 \mathrm{E}+00$ & $0.00 \mathrm{E}+00$ & & \\
\hline & 81 & 798 & $6.62 \mathrm{E}-03$ & 6.41 & 21.03 & 51 & $0.00 \mathrm{E}+00$ & $0.00 \mathrm{E}+00$ & & \\
\hline & 82 & 341 & $2.83 \mathrm{E}-03$ & 6.38 & 20.93 & 51.1 & $0.00 \mathrm{E}+00$ & $0.00 \mathrm{E}+00$ & & \\
\hline & $\begin{array}{l}\text { Total } \\
\text { Pixels: }\end{array}$ & 120485 & & & & & & & & \\
\hline
\end{tabular}




\section{References}

1. Naidu, M.S. and Kamaraju, V., High Voltage Engineering, McGraw-Hill Professional, New York, 1996, pp. 13-14.

2. Ferguson, D.C., and Hillard, G.B., "Paschen Considerations for High Altitude Airships," AIAA Aerospace Sciences Meeting and Exhibit, AIAA-2004-1260, Reno NV, 2004, p. 3.

3. Liu, C., and Glassford, A.P.M., "Contamination Effect of MMH/N2O4 Rocket Plume Product Deposit," Journal of Spacecraft and Rockets, vol. 18, no. 4, 3 March 1981, pp. 306, 309.

4. Ma, P.T., "Computation of Solar Array Power Loss from MMH/HNO3 Rocket Motor Plume Contamination," AIAA Thermophysics Conference, AIAA-91-1330-CP, Honolulu, Hawaii, June 24-26, 1991, pp. 2-4.

5. Larin, M., Lumpkin, F., and Stuart, P., "Modeling Unburned Propellant Droplet Distribution and Velocities in Plumes of Small Bipropellant Thrusters," AIAA Thermophysics Conference, AIAA2001-2816, Anaheim, CA, June 11-14, 2001, pp. 10.

6. Pankop, C., Alred, J., and Boeder, P., "Mitigation of Thruster Plume Erosion of International Space Station Solar Array Coatings," Journal of Spacecraft and Rockets, vol. 43, no. 3, June 3, 2006, pp. 545, 548.

7. Rauschenbach, H.S., "Solar Cell Array Design Handbook: Volume 1," NASA CR-149364, 1976.

8. Koontz, S., Melendez, O., Zolensky, M., and Soares, C., "SPIFEX Contamination Studies," JSC 27399, 1996.

9. Alred, J., Boeder, P., Mikatarian, R., Pankop, C., and Schmidl, W., "Modeling of Thruster Plume Induced Erosion," International Symposium on Materials in a Space Environment, ESA SP-540, June 16-20, 2003, p. 387. 


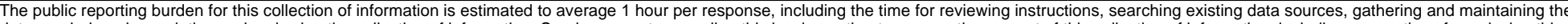

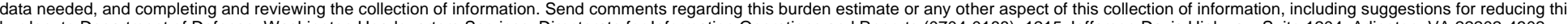

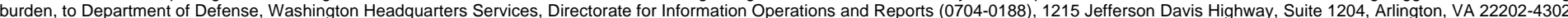

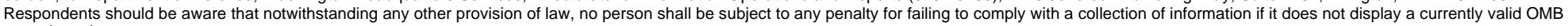
control number.

PLEASE DO NOT RETURN YOUR FORM TO THE ABOVE ADDRESS.

\section{REPORT DATE (DD-MM-YYYY) \\ 2. REPORT TYPE \\ 3. DATES COVERED (From - To)}

01-07-2008

\section{TITLE AND SUBTITLE}

Technical Memorandum

The Effect of Reaction Control System Thruster Plume Impingement on Orion Service

Module Solar Array Power Production

\section{5a. CONTRACT NUMBER}

5b. GRANT NUMBER

5c. PROGRAM ELEMENT NUMBER

\section{AUTHOR(S)}

Bury, Kristen, M.; Kerslake, Thomas, W.

\section{5d. PROJECT NUMBER}

5e. TASK NUMBER

5f. WORK UNIT NUMBER

WBS 644423.06.32.03.05.03

\section{PERFORMING ORGANIZATION NAME(S) AND ADDRESS(ES)}

National Aeronautics and Space Administration

8. PERFORMING ORGANIZATION

REPORT NUMBER

John H. Glenn Research Center at Lewis Field

E-16593

Cleveland, Ohio 44135-3191

\section{SPONSORING/MONITORING AGENCY NAME(S) AND ADDRESS(ES)}

National Aeronautics and Space Administration

Washington, DC 20546-0001

\section{SPONSORING/MONITORS ACRONYM(S) \\ NASA \\ 11. SPONSORING/MONITORING REPORT NUMBER \\ NASA/TM-2008-215423}

\section{DISTRIBUTIONIAVAILABILITY STATEMENT}

Unclassified-Unlimited

Subject Categories: 18 and 20

Available electronically at http://gltrs.grc.nasa.gov

This publication is available from the NASA Center for AeroSpace Information, 301-621-0390

\section{SUPPLEMENTARY NOTES}

\section{ABSTRACT}

NASA's new Orion Crew Exploration Vehicle has geometry that orients the reaction control system (RCS) thrusters such that they can impinge upon the surface of Orion's solar array wings (SAW). Plume impingement can cause Paschen discharge, chemical contamination, thermal loading, erosion, and force loading on the SAW surface, especially when the SAWs are in a worst-case orientation (pointed $45^{\circ}$ towards the aft end of the vehicle). Preliminary plume impingement assessment methods were needed to determine whether in-depth, timeconsuming calculations were required to assess power loss. Simple methods for assessing power loss as a result of these anomalies were developed to determine whether plume impingement induced power losses were below the assumed contamination loss budget of 2 percent. This paper details the methods that were developed and applies them to Orion's worst-case orientation.

\section{SUBJECT TERMS}

Solar arrays; Plumes; Impingement; Solar cells; Heat flux

\begin{tabular}{|c|c|c|c|}
\hline \multicolumn{3}{|c|}{ 16. SECURITY CLASSIFICATION OF: } & $\begin{array}{l}\text { 17. LIMITATION OF } \\
\text { ABSTRACT }\end{array}$ \\
\hline $\begin{array}{l}\text { a. REPORT } \\
\mathrm{U}\end{array}$ & $\begin{array}{l}\text { b. ABSTRACT } \\
\text { U }\end{array}$ & $\begin{array}{l}\text { c. THIS } \\
\text { PAGE } \\
\text { U }\end{array}$ & UU \\
\hline
\end{tabular}

18. NUMBER
OF
PAGES
31
19a. NAME OF RESPONSIBLE PERSON STI Help Desk (email:help@sti.nasa.gov) 19b. TELEPHONE NUMBER (include area code) 301-621-0390



